Nig. J. Biotech. Vol. 38 (1) : 1-13 (June 2021)

ISSN: 01891731

Available online at

http://www.ajol.info/index.php/njb/index

and www.biotechsocietynigeria.org

DOI: https://dx.doi.org/10.4314/njb.v38i1.1

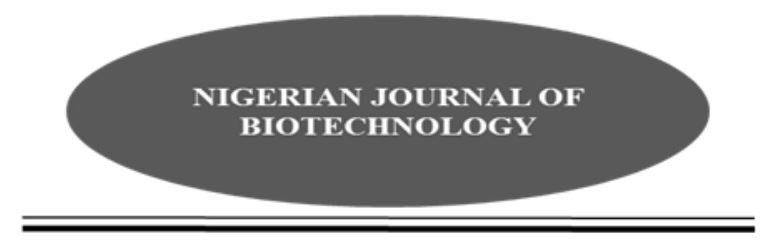

\title{
Antimicrobial Efficacy of Vitellaria paradoxa fractions and compounds on some wood Fungi and Bacteria
}

\author{
*Ekhuemelo, D. 0. ${ }^{1}$, Anyam, J. V. ${ }^{2}$, and Ekhuemelo, C. ${ }^{3}$ \\ ${ }^{1}$ Department of Forest Production and Products, Federal University of Agriculture Makurdi, Nigeria \\ 2Department of Chemistry, Federal University of Agriculture Makurdi, Nigeria \\ ${ }^{3}$ Department of Crop and Environmental Protection, Federal University of Agriculture Makurdi, Nigeria
}

\begin{abstract}
This study examined antifungal efficacy of Vitellaria paradoxa fractions and compounds in the control of some wood degrading fungi. Stem bark and heartwood parts of Vitellaria paradoxa were collected, dried, pulverised and macerated sequentially in $\mathrm{n}$ - hexane, methanol and ethyl acetate solvents. The mixtures were filtered, evaporated and the dried samples were mixed and run over silica gel in column chromatography with a mixture of $\mathrm{n} \quad$-hexane and ethyl acetate solvents to obtain fractions. The fractions collected were evaporated and those with white needles were subjected to Magnetic Resonance (NMR) spectroscopic analysis. Spinasterol was isolated and characterised from the heartwood fraction while the stem bark fractions were fatty. Vitellaria paradoxa fractions were active against Serpula lacrymans, Sclerotium rolfsii, Aspergillus fumigatus, Fomitopsis pinicoca, Phaeolus schweinitzii, Rhizopus sp., Coniophora puteana, Gloeophyllum sepiarium, and Fibroporia vaillantii at zones of inhibition (ZOI) of 18 $\mathrm{mm}-24 \mathrm{~mm}$. Although the antibiotics were active $(25-31 \mathrm{~mm})$, they were found inactive against the Fomitopsis pinicoca fungus which was sensitive to all the $V$. paradoxa fractions at zones of inhibition of 18 - $24 \mathrm{~mm}$. The minimum inhibitory concentrations (MIC) of the $V$. paradoxa fractions were active at $50 \mu \mathrm{g} / \mathrm{mL}$ against all test fungi. At minimum fungicidal concentration (MFC) of between $50-200 \mu \mathrm{g} / \mathrm{mL}$, all the test fungi were killed. Based on the ZOI, MIC and MFC, the $V$. paradoxa stem bark heartwood fractions have been proven to be very efficient in inhibiting the growth of test wood rot fungi; hence the species could be explored as a potential source of bioactive fungicides.
\end{abstract}

Keywords: Bacteria, Compound, Fraction, Fungi, Spinasterol, Vitellaria paradoxa

*Corresponding author Email: davidekhuemelo@gmail.com, Tel: +234-7031332803

\section{Introduction}

Vitellaria paradoxa (C. F. Gaertn) formally referred to as Butyrospermum parkii and Butyrospermum paradoxa belongs to the family Sapotaceae. It is commonly known as Shea tree or Shea butter tree (IPGRI, INIA. 2006). In English, it is called Shea butter tree; Shea nut tree; karate in French (Teketay et al., 2003); Ka'danya, Kadanya, Mankade in Hausa; Okwuma, Osisi in Igbo (Audu \& Awulu, 2017), Ori, Emi in Yoruba (Animasaun et al., 2019), and Chamegh in Tiv (Shomkegh et al., 2016). The Shea butter tree is of average height of $10-15 \mathrm{~m}$ with dense spreading canopy, thick, dark and fissured bark (ICRAF, 2000). This species is known both as a fruit tree and as an oilseed crop (Ugese et al., 2008).

The species originated in African and is found in areas with $400-1800 \mathrm{~mm}$ rainfall per year (IPGRI, INIA. 2006). It either grows naturally or is farmed as a tree crop in the arid Savanna region of West Africa countries (Audu \& Awulu, 2017). It is believed to have spread from Senegal in West Africa to Uganda in East Africa till Adamaoua Province in Cameroon which is in North-South 
Africa (IPGRI, INIA. 2006). Vitellaria paradoxa grows in the wild area of dry savannah region of West Africa from Senegal in the west to Sudan in the east to the foothills of Ethiopian highlands. This species also grows in nineteen countries of Africa. Namely Burkina Faso, Ghana, Chad, Cameroon, Central African Republic, Ethiopia, Niger, Ivory Coast, Mali, Nigeria, Sierra Leone, Guinea Bissau, Togo Uganda, Zaire, Senegal, Guinea, Benin and Sudan (Warra, 2011).

Vitellaria paradoxa is multipurpose agroforestry indigenous tree species that contribute immensely to the livelihood of rural communities for income generation and as source of raw material for many industries. The ripe fruits are eaten as a snack and as famine food. Shea butter, or Shea oil, is a raw material used in factories to manufacture margarine, baking fat, cocoa butter substitutes as well as different pharmaceutical and moisturising beauty products (IPGRI, INIA. 2006). Shea butter leaves are good forage for animal feeding, soil improvement (Ziblim et al., 2015). The species has the capacity to improve nutrition, increase healthcare, decrease rural poverty and aid sustainable land care (Moore, 2008). The wooden stem is resistant to termites and a good timber used for various constructing purposes.

Several authors have reported the use of Shea butter in medicine (Prescott et al., 2002; ElMahmoud et al., 2008; Ahmed and Sani, 2013; Ahmed et al., 2012; Fodouop et al., 2015). It is used in the treatment of rheumatic and joint pains and healing of wounds, managing swellings and bruises, dermatitis and other skin (Fodouop et al., 2015). Some people have been reported to consume extract of $V$. paradoxa for treatment of various bacterial and fungal infections (Kalgo et al., 2019). The stem back extract possesses immunomodulatory properties which have effect on human neutrophils viability and function (Kalgo et al., 2019) and contain antioxidant constituents with antimicrobial activities (Olasunkanmi et al., 2017). Shea tree bark, if purified, could be used to produce an antiseptic agent capable of treating skin infections caused by groups of fungi (Ahmed et al., 2009).

Vitellaria paradoxa has been researched as an effective medicinal plant (Prescott et al., 2002).
It has proved to be active against bacterial and fungal diseases (El-Mahmoud et al., 2008; Ahmed and Sani, 2013). The barks, leaves and roots extracts of $V$. paradoxa contain phytochemical constituents inhibits growth of some dermatophytes (Boyejo et al., 2019) and could be used as a potential source of antibiotic substance for a drug development (Ajijolakewu and Awarun, 2015). Vitellaria paradoxa may be used as potent sources of bioactive substances in the production of drugs against diseases caused by superficial and enteric organisms (Ajijolakewu and Awarun, 2015). The leaf, stem bark, and seed of shea tree contain a host of bioactive compounds that can be utilized in the control of infections caused by T. mentagrophyte, $A$. fumigatus, $E$. flocossum, $T$. rubrum, and M. Audouinii (Ahmed et al., 2012).

Wood is versatile and can be used for a very long time but it is subject to biodeterioration. Wood deterioration is a very essential process in the environment that recycles complex organic materials and it is a fundamental component of life (Blanchette, 2000). Primarily, fungi, inserts, ants and bacteria are some of the agents of deterioration. Wood decay fungi are classified into two major groups: white- and brown-rot fungi (Blanchette, 2000). White rot fungi can degrade all cell wall components, including lignin. They cause bleaching of common wood colouration, metabolize large amounts of lignin in wood is unique among microorganisms, degrade cells and reduce the strength properties of wood in the late stages of decay. On other hand, brown-rot fungi depolymerise cellulose quickly during initial stages of wood colonization. Substantial losses in wood strength start very early in the decay process, frequently before decay evidence is visually shown (Blanchette, 2000). Bacteria are known to have the ability to decompose wood cellulose although their influence on wood decay is restricted. Different bacteria from woodland soil contain enzymes used in the breakdown of cellulose and cellulose products (Llado' et al., 2015).

Fungi and bacteria play a major role in the well being, diversity, and productivity of forest ecosystems. Fungi feed on woody products and serve to recycle nutrients. As a result, they physically and chemically break down wood products thereby causing lots of economic hazards (Marcot, 2007). Despite the many studies 
that have been done on the medicinal and antimicrobial properties of $V$. paradoxa, not much has been done on the effect of $V$. paradoxa activity on wood degrading fungi and bacteria. Therefore, this study was undertaken to evaluate the compounds present in the stem bark and heartwood fractions of $V$. paradoxa and assess their effect on selected wood decay fungi and bacteria.

\section{Materials and Methods}

Plant parts Collection and preparation
Stem bark of $V$. paradoxa was collected from the wild at the Federal University of Agriculture, Makurdi campus, located between longitudes $8^{\circ}$ $21^{\prime}$ and $9^{\circ} \mathrm{E}$ and latitudes $7^{\circ} 21^{\prime}$ and $8^{\circ} \mathrm{N}$ in Benue State, Nigeria, within the southern guinea savannah ecological zone (Seibert, 2007). The stem bark was air- dried during harmattan season and pulverised. The heartwood was sawn at Makurdi Head Bridge Timber Shed to collect its sawdust which was also dried to avoid being damp.
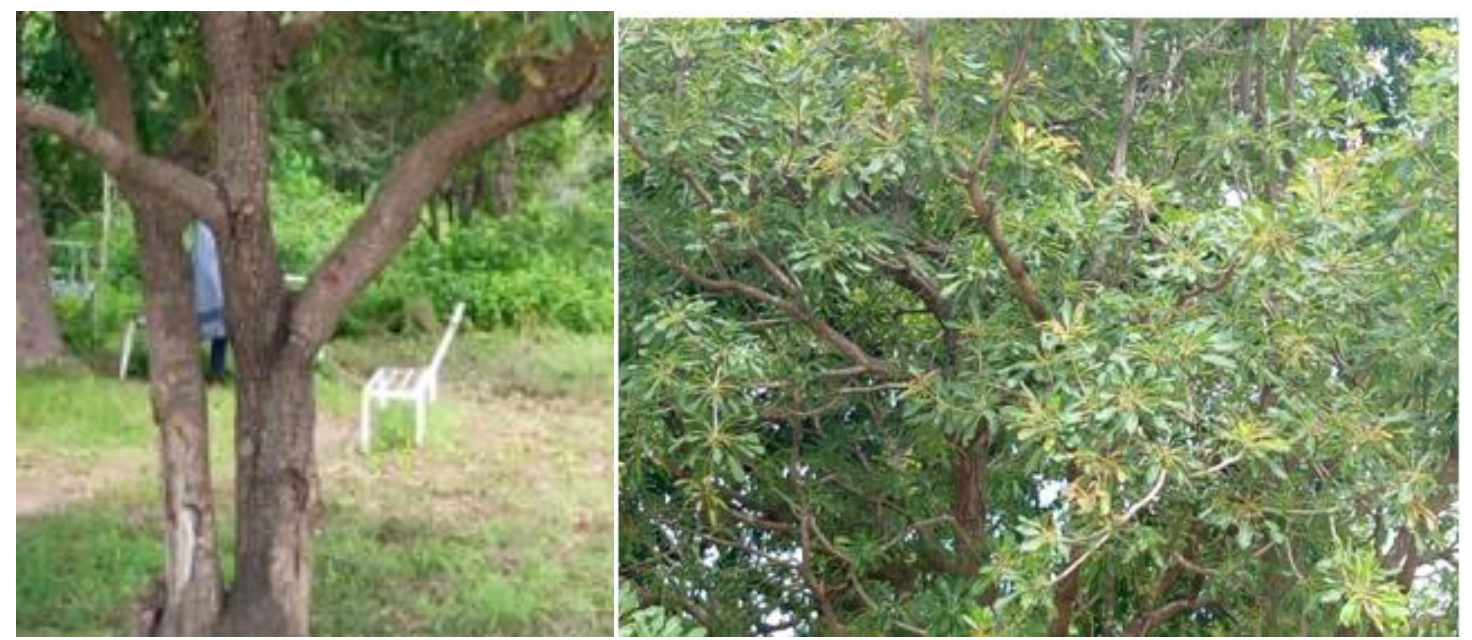

Plate 1: Stem and canopy of Vitellaria paradoxa tree at College of Animal Science, FUAM

\section{Extraction of plant materials}

Extraction of $V$. paradoxa stem bark and heartwood was done successively by dissolving $1,000 \mathrm{~g}$ and $600 \mathrm{~g}$ of stem bark and heartwood, respectively, into $1,000 \mathrm{~mL}(\mathrm{w} / \mathrm{v})$ of $\mathrm{n}$-hexane for 24 hours, followed by filtration of the $n^{\prime}$ hexane extract. The residue left from the hexane extraction was again macerated with ethyl acetate and methanol, respectively, for 24 hours each. The mixtures were filtered with Whatman No.1 filter papers into well labelled glass bottles as $n$-hexane, ethyl acetate and methanol extracts, respectively. The filtrates were evaporated to obtain dried extracts (Plate 1). 


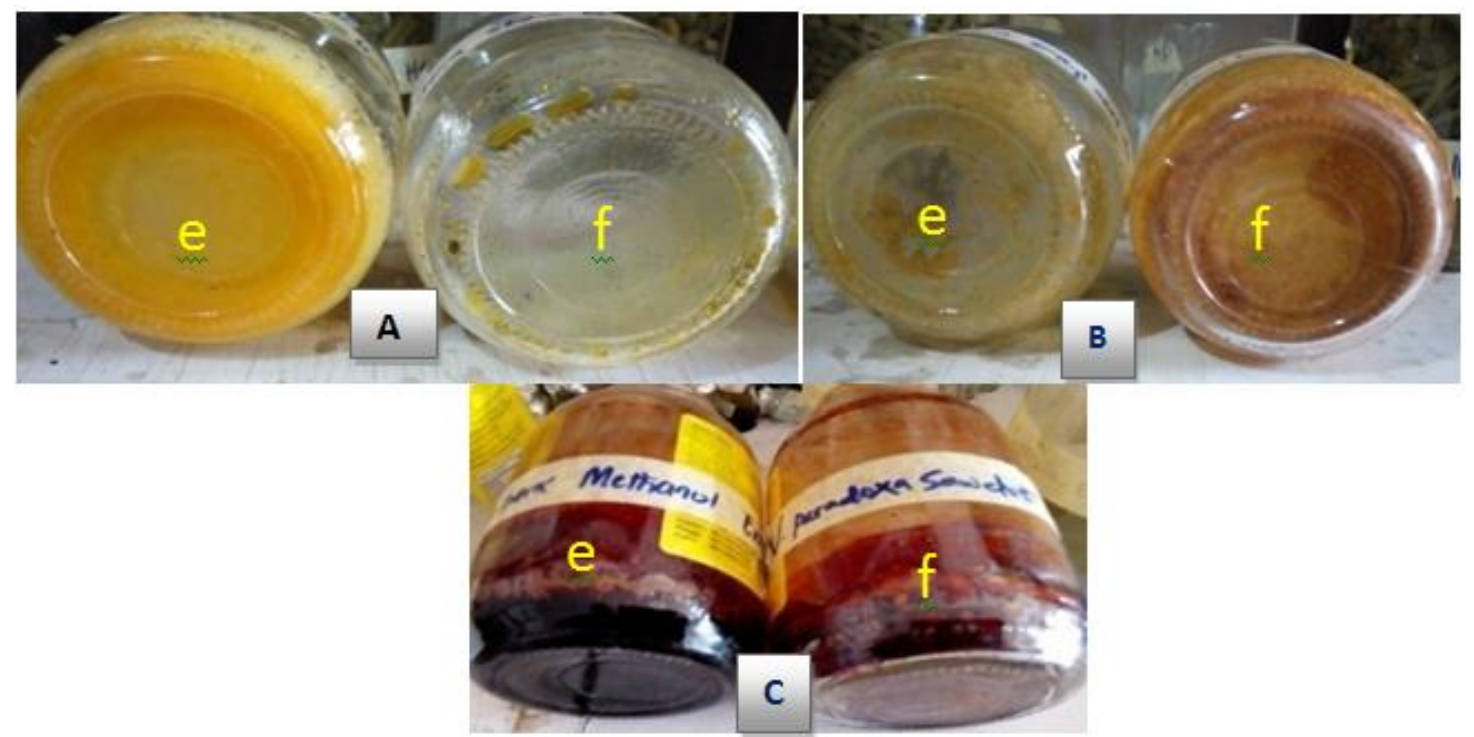

Key: [A] N' Hexane extracts, [B] Ethyl acetate extracts [C] Methanol extracts [e] Dried filtrate of stem bark extracts [f], Dried filtrate of sawdust extracts

Plate 1: Dried samples of $V$. paradoxa heartwood (sawdust) and Stem Bark Extracts

Column Chromatography and Nuclear Magnetic Resonance (NMR) spectroscopic analysis

Dried crude mixture of $n$-hexane and ethyl acetate extracts was run over silica gel with solvent mixtures of successive increasing polarity of hexane and ethyl acetate in the ratio of 95:5 $0: 100$, respectively, in column to produce pure compounds or fractions according to Ekhuemelo et al. (2018). The fractions of the pure compounds were collected in well- labelled vials and allowed to dry (Plate 2). Nuclear Magnetic Resonance (NMR) spectroscopic analysis was done on selected fractions which contained white needle-shaped crystals. NMR data was acquired on a Bruker-Avance $500 \mathrm{MHz}$ spectrometer. The NMR data was processed using MestreNova $₫ 12$ software. The characterization was done using the ${ }^{1} \mathrm{H}$ NMR data.

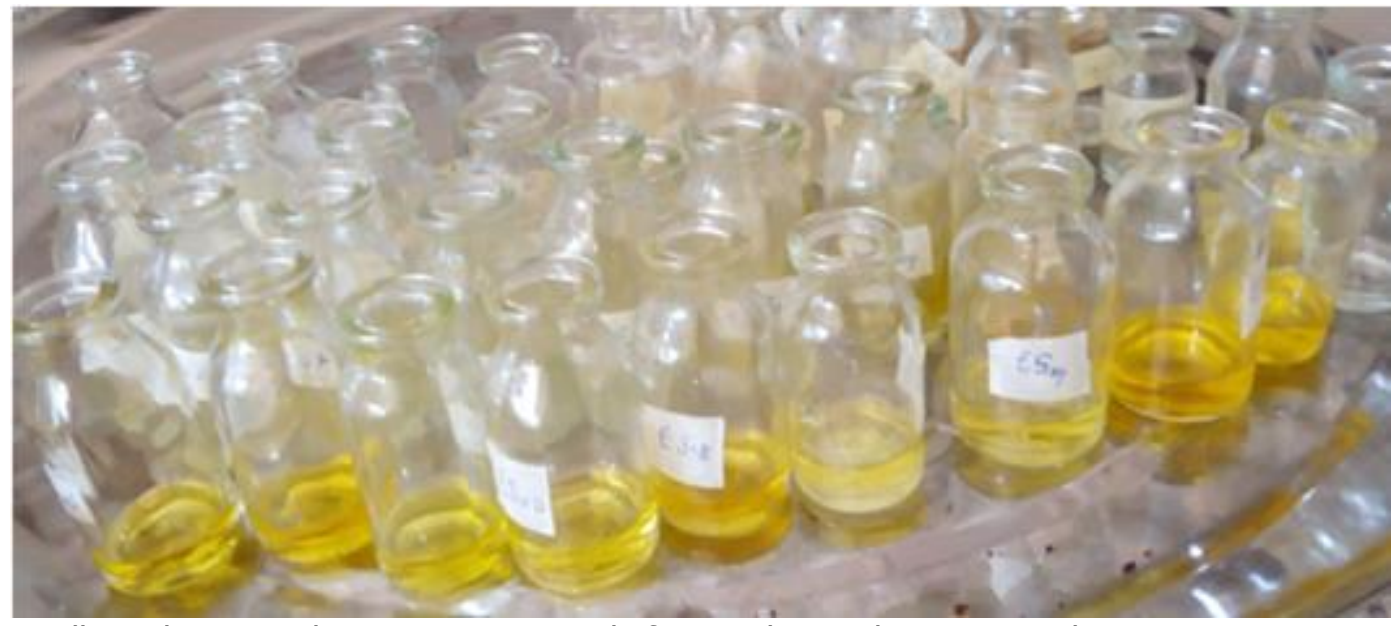

Plate 2: Collected V. paradoxa Fractions in Vials from Column Chromatography

Standardization of the test bacteria and fungi

Standardized inoculums of each test fungus (Serpula lacrymans Sclerotium rolfsii, Aspergillus fumigatus, Fomitopsis pinicoca, Phaeolus schweinitzii, Rhizopus sp., Coniophora puteana, Gloeophyllum sepiarium, and Fibroporia vaillantii) and each test bacterium

(Acidobacterium 
capsulatum, Actinobacteria sp. Agrobacterium tumefaciens, Bacillus subtilis Ralstonia solanacearum, Enterococcus faecium, Pseudomonas syringae, Escherichia coli, Proteus mirabilis and Pseudomonas aeruginosa) were achieved by preparing their respective suspensions up to 0.5 McFarland standards. The growth of the actively growing culture in the broth was altered with sterile saline or broth to obtain turbidity that was clearly comparable to that of the 0.5 McFarland standards according to Lalitha, (2004); Kuta et al. (2017).

\section{Determination of antimicrobial activity of Vitellaria paradoxa fractions}

The activity of $V$. paradoxa fractions on test and bacteria and fungi samples was investigated using agar diffusion method. Concentrations of $200 \mu \mathrm{g} / \mathrm{mL}$ and $100 \mu \mathrm{g} / \mathrm{mL}$ were prepared from each fraction and antibiotics respectively. The antibiotics used as control were Ketoconazole, fluconazole and Fulcin for fungi; and ciprofloxacin, sparfloxacin and cefuroxime for bacteria according to Ekhuemelo et al. (2018). The Muller-Hinton and Sabouraud Dextrose agar were used in the culture of bacteria and fungi, respectively. The incubation of test fungi was made at $30^{\circ} \mathrm{C}$ for 7 days and at $37^{\circ} \mathrm{C}$ for 24 hours for bacteria. During the period plates of the media were observed for inhibition of growth. Zones of inhibition were measured and results recorded in millimetres $(\mathrm{mm})$.

\section{Minimum inhibitory concentration (MIC)/}

Minimum Fungicidal concentration (MFC)

The MIC of the antifungal fractions and compounds was determined by broth dilution methods. Different concentrations $(200 \mu \mathrm{g} / \mathrm{mL}$, $100 \mu \mathrm{g} / \mathrm{mL}, 50 \mu \mathrm{g} / \mathrm{mL}, 25 \mu \mathrm{g} / \mathrm{mL}$ and 12.5 $\mu \mathrm{g} / \mathrm{mL}$ ) of fractions were added to media in the Petri dishes and inoculated with the test fungi. The mixture was incubated and examined for growth according to Ekhuemelo et al. (2018). The lowest concentration of the fraction that inhibits visible growth of the test fungi was recorded as the MIC.

The MFC of the fraction was determined by subculturing the contents of the Petri dishes that showed inhibition on Muller-Hinton and Sabouraud Dextrose agar plates for bacteria and fungi, respectively, while the absence of growth on incubation was recorded as MFC.

\section{Results}

Characterization of VPH22 as Spinasterol

Vitellaria paradoxa heartwood fraction (VPH22) was obtained as white needles. It's proton nuclear magnetic resonance spectrum ( $\left.{ }^{1} \mathrm{H}-\mathrm{NMR}\right)$ gave the following data (Figure 1) below: ${ }^{1} \mathrm{H}$ NMR (500 MHz, Chloroform- $d$ ) $\delta 5.19-5.13(\mathrm{~m}, 2 \mathrm{H})$, 5.03 (dd, $J=15.1,8.6 \mathrm{~Hz}, 1 \mathrm{H}), 3.60(\mathrm{tt}, J=10.7$, $4.4 \mathrm{~Hz}, 2 \mathrm{H}), 2.34(\mathrm{t}, J=7.5 \mathrm{~Hz}, 2 \mathrm{H}), 2.09-1.96$ $(\mathrm{m}, 6 \mathrm{H}), 1.03(\mathrm{~d}, J=6.6 \mathrm{~Hz}, 3 \mathrm{H}), 0.88(\mathrm{~s}, 2 \mathrm{H})$, $0.86(\mathrm{~s}, 3 \mathrm{H}), 0.84(\mathrm{~s}, 3 \mathrm{H}), 0.82(\mathrm{~s}, 1 \mathrm{H}), 0.81(\mathrm{~s}$, $2 \mathrm{H}), 0.80(\mathrm{~s}, 8 \mathrm{H}), 0.55(\mathrm{~s}, 2 \mathrm{H})$. The signals at $\delta$ $5.19-5.13(\mathrm{~m}, 2 \mathrm{H})$ and $5.03(\mathrm{dd}, J=15.1,8.6$ $\mathrm{Hz}, 1 \mathrm{H})$, indicate the presence of olefinic bonds (Alexandri et al., 2017), while that at $3.60(\mathrm{tt}, J$ $=10.7,4.4 \mathrm{~Hz}, 1 \mathrm{H}$ ) indicate an oxymethine proton (Sun and Yasukawa, 2008); signals at $2.34(\mathrm{t}, J=7.5 \mathrm{~Hz}, 2 \mathrm{H})$ and $2.09-1.96(\mathrm{~m}, 6 \mathrm{H})$ are representative of methine and methylene protons. The signals at $1.03(\mathrm{~d}, J=6.6 \mathrm{~Hz}, 3 \mathrm{H})$, $0.88(\mathrm{~s}, 2 \mathrm{H}), 0.86(\mathrm{~s}, 3 \mathrm{H}), 0.84(\mathrm{~s}, 3 \mathrm{H}), 0.81(\mathrm{~s}$, $3 \mathrm{H})$ and $0.55(\mathrm{~s}, 3 \mathrm{H})$ are due to methyl protons (Cheung, and Williamson, 1969). The data acquired was reminiscent of that for sterols and triterpenes. A literature look up revealed the data to be unambiguously identical to that of spinasterol (Villaseñor and Domingo, 2008). Vitellaria paradoxa heartwood fraction (VPH22) was characterised as Spinasterol (Figure 2). 


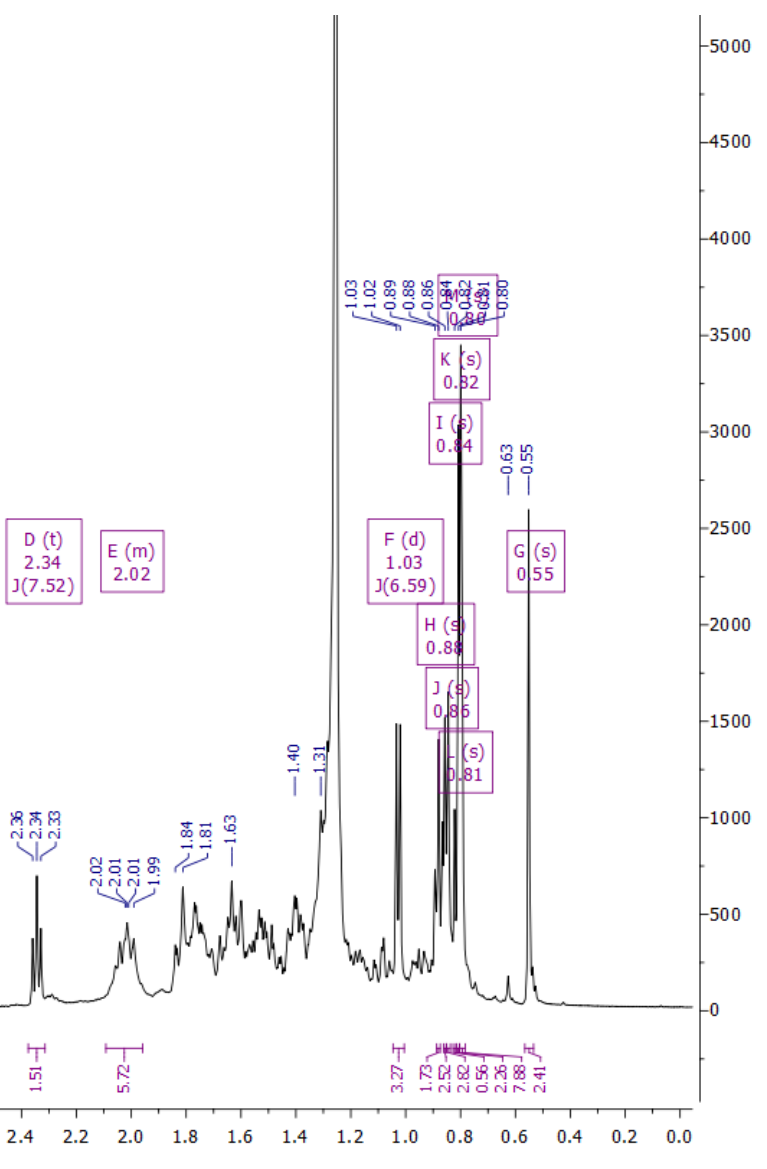

Figure 1: Proton NMR Spectrum of Vitellaria paradoxa heartwood fraction (VPH22)

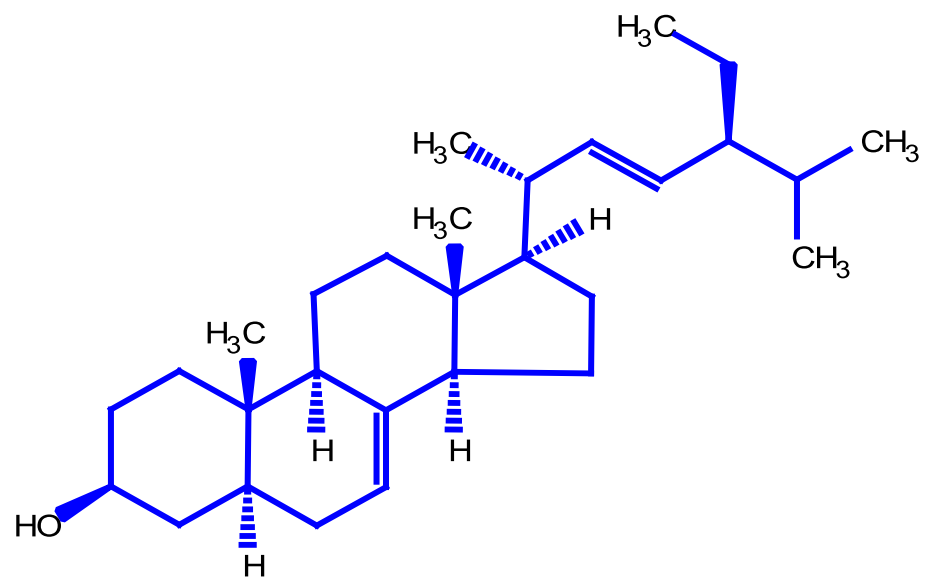

Figure 2: Structure of VPH22 (Spinasterol)

Effect of Antifungal activities of $V$. paradoxa fractions and Antibiotics against test fungi The test fungi were sensitive to all the $V$. paradoxa fractions (VP17, VP28, VP34, VP47, VP23, VP134, and $\mathrm{VPH} 22$ ) at zones of inhibition (ZOI) of between 18 and $24 \mathrm{~mm}$ (Table 1). Aspergillus fumigatus, Coniophora puteana, Fomitopsis pinicoca, Gloeophyllum sepiarium,
Phaeolus schweinitii, Rhizopus sp. and Serpula lacrymans were sensitive to $V$. paradoxa stem bark fraction (VP17) with ZOI of between $20 \mathrm{~mm}$ to $24 \mathrm{~mm}$. It was also observed that Coniophora puteana, Fibroporia vaillantii, Fomitopsis pinicoca, Gloeophyllum sepiarium, Rhizopus sp., Serpula lacrymans and Sclerotium rolfsii were sensitive to $V$. paradoxa stem 
bark fraction (VP28) with ZOI ranging between $20 \mathrm{~mm}$ and $24 \mathrm{~mm}$ while the antibiotics were active on all test fungi at ZOI of $25-31 \mathrm{~mm}$ except $F$. pinicoca which was resistant.

Effect of Minimum inhibition concentration (MIC) of $V$. paradoxa Fraction against test fungi

At the minimum inhibition concentration (MIC) of $50 \mu \mathrm{g} / \mathrm{mL}$, VP23 fraction prevented the growth of Aspergillus fumigatus, Phaeolus schweinitzii, Rhizopus sp. and Serpula lacrymans test pathogens (Table 2). Also, at $50 \mu \mathrm{g} / \mathrm{mL}, V$. paradoxa stem bark fraction (VP34) stopped the growth of Aspergillus fumigatus, Fibroporia vaillantii, Fomitopsis pinicoca, Phaeolus schweinitzii,, Rhizopus sp. and Serpula lacrymans test pathogens while, $V$. paradoxa heartwood fraction (VP22) only inhibited Coniophora puteana, Fibroporia vaillantii, Rhizopus sp. and Serpula lacrymans test pathogens. However, at100 $\mu \mathrm{g} / \mathrm{mL}$, Fibroporia vaillantii and Fomitopsis pinicoca growth was prevented by VP23 isolate while Coniophora puteana and Fibroporia vaillantiigrowths were inhibited by $V$. paradoxa stem bark fraction (VP134).

Effect of Minimum Fungicidal concentration of $V$. paradoxa fractions on test Fungi

Table 2 presents the MFC of $V$. paradoxa fractions of VP17, VP28, VP34, VP47, VP23, VPH22 and VP134 against test fungi. VP134 fraction was the most active fraction compared to the rest as it completely inhibited the growths of Fomitopsis pinicoca, Rhizopus sp. and Serpula lacrymans at MFC of $50 \mu \mathrm{g} / \mathrm{mL}$. At $100 \mu \mathrm{g} / \mathrm{mL}$, VPH22 fraction killed Fomitopsis pinicoca while VP134 fraction completely stopped the growth of Coniophora puteana and Fibroporia vaillantii. At $200 \mu \mathrm{g} / \mathrm{mL}$ rest fractions killed all the test fungi.

Table 1: Sensitivity of Vitellaria paradoxa Fractions and Standard Antibiotics against Test Fungi

\begin{tabular}{|c|c|c|c|c|c|c|c|c|c|c|c|}
\hline \multirow[t]{2}{*}{$\begin{array}{l}\text { S/ } \\
\text { No }\end{array}$} & \multirow[t]{2}{*}{ Test fungi } & \multicolumn{7}{|c|}{$\begin{array}{c}\text { Zone of Inhibition }(\mathrm{mm}) \text { of Vitellaria } \\
\text { paradoxa Fractions } \\
(200 \mu \mathrm{g} / \mathrm{mL})\end{array}$} & \multicolumn{3}{|c|}{$\begin{array}{c}\text { Zone of Inhibition }(\mathrm{mm}) \text { of } \\
\text { Antibiotic } \\
(\mathbf{1 0 0} \mathrm{\mu g} / \mathrm{mL})\end{array}$} \\
\hline & & $\begin{array}{c}\text { VP1 } \\
7\end{array}$ & $\begin{array}{c}\text { VP2 } \\
8\end{array}$ & $\begin{array}{c}\text { VP3 } \\
4\end{array}$ & $\begin{array}{l}\text { VP } \\
47\end{array}$ & $\begin{array}{c}\text { VP2 } \\
3\end{array}$ & $\begin{array}{c}\text { VP } \\
134\end{array}$ & $\begin{array}{c}\text { VPH } \\
22\end{array}$ & $\begin{array}{c}\text { Flucona } \\
\text { zole }\end{array}$ & $\begin{array}{c}\text { Fulci } \\
\text { n }\end{array}$ & $\begin{array}{c}\text { Ketoconazo } \\
\text { le }\end{array}$ \\
\hline 1 & S. rolfsii & 0 & 21 & 24 & 21 & 0 & 0 & 0 & 0 & 0 & 25 \\
\hline 2 & $\begin{array}{l}\text { S. } \\
\text { lacrymans }\end{array}$ & 21 & 20 & 23 & 20 & 21 & 23 & 20 & 0 & 30 & 30 \\
\hline 4 & $\begin{array}{l}\text { Rhizopus } \\
\text { sp. }\end{array}$ & 20 & 23 & 0 & 24 & 23 & 21 & 22 & 0 & 29 & 27 \\
\hline 3 & $\begin{array}{l}\text { P. } \\
\text { schweinitiil, }\end{array}$ & 20 & 0 & 20 & 23 & 20 & 0 & 21 & 0 & 25 & 0 \\
\hline 5 & $\begin{array}{l}\text { G. } \\
\text { sepiarium }\end{array}$ & 24 & 21 & 21 & 0 & 0 & 0 & 0 & 29 & 0 & 28 \\
\hline 6 & F. vaillantii & 23 & 20 & 22 & 0 & 19 & 20 & 23 & 0 & 28 & 0 \\
\hline 7 & F. pinicoca & 0 & 24 & 0 & 0 & 18 & 19 & 21 & 0 & 0 & 0 \\
\hline 8 & C. puteana & 21 & 23 & 20 & 23 & 0 & 18 & 0 & 0 & 31 & 0 \\
\hline 9 & $\begin{array}{l}\text { A. } \\
\text { fumigatus }\end{array}$ & 20 & 0 & 20 & 0 & 21 & 0 & 20 & 0 & 29 & 25 \\
\hline
\end{tabular}

Key: $\mathrm{R}=$ Resistance, VP = Vitellaria paradoxa stem bark, VPH= Vitellaria paradoxa heartwood, ZOI $<10$ $\mathrm{mm}$ is inactive; $10-13 \mathrm{~mm}$ is partially active; $14-19 \mathrm{~mm}$ is active, and $>19 \mathrm{~mm}$ is very active.

Table 2: Minimum Inhibition Concentration and Minimum Fungicidal Concentration of Vitellaria paradoxa against Test Fungi 


\begin{tabular}{|c|c|c|c|c|c|c|c|c|c|c|c|c|c|c|c|}
\hline \multirow[t]{2}{*}{$\begin{array}{l}\text { S/ } \\
\text { No }\end{array}$} & \multirow[t]{2}{*}{ Test Fungi } & \multicolumn{2}{|c|}{$\begin{array}{c}\text { VP17 } \\
(\mu \mathrm{g} / \mathrm{mL})\end{array}$} & \multicolumn{2}{|c|}{$\begin{array}{c}\text { VP28 } \\
(\mu \mathrm{g} / \mathrm{mL})\end{array}$} & \multicolumn{2}{|c|}{$\begin{array}{c}\text { VP34 } \\
(\mu \mathrm{g} / \mathrm{mL})\end{array}$} & \multicolumn{2}{|c|}{$\begin{array}{c}\text { VP47 } \\
(\mu \mathrm{g} / \mathrm{mL})\end{array}$} & \multicolumn{2}{|c|}{$\begin{array}{c}\text { VP23 } \\
(\mu \mathrm{g} / \mathrm{mL})\end{array}$} & \multicolumn{2}{|c|}{$\begin{array}{c}\text { VPH } 22 \\
(\mu \mathrm{g} / \mathrm{mL})\end{array}$} & \multicolumn{2}{|c|}{$\begin{array}{c}\text { VP } 134 \\
(\mu \mathrm{g} / \mathrm{mL})\end{array}$} \\
\hline & & MI & $\begin{array}{c}\text { MF } \\
\text { C }\end{array}$ & MI & $\begin{array}{c}\text { MF } \\
\text { C }\end{array}$ & MI & $\begin{array}{c}\text { MF } \\
\text { C }\end{array}$ & $\begin{array}{c}\text { MI } \\
\text { C }\end{array}$ & $\begin{array}{c}\text { MF } \\
\text { C }\end{array}$ & $\begin{array}{c}\text { MI } \\
\text { C }\end{array}$ & $\begin{array}{c}\text { MF } \\
\text { C }\end{array}$ & MIC & $\begin{array}{c}\text { MF } \\
\text { C }\end{array}$ & MIC & $\begin{array}{c}\text { MF } \\
\text { C }\end{array}$ \\
\hline 1 & S. rolfsii & $\mathrm{R}$ & $\mathrm{R}$ & 50 & 200 & 50 & 100 & 50 & 200 & $\mathrm{R}$ & $\mathrm{R}$ & $\mathrm{R}$ & $\mathrm{R}$ & $\mathrm{R}$ & $\mathrm{R}$ \\
\hline 2 & S. lacrymans & 50 & 200 & 50 & 200 & 50 & 100 & 50 & 200 & 50 & 200 & 50 & 200 & 50 & 50 \\
\hline 4 & Rhizopussp. & 50 & 200 & 50 & 200 & $\mathrm{R}$ & $\mathrm{R}$ & 50 & 100 & 50 & 200 & 50 & 200 & 50 & 50 \\
\hline 3 & $\begin{array}{l}\text { P. } \\
\text { schweinitzii, }\end{array}$ & 50 & 200 & $\mathrm{R}$ & $\mathrm{R}$ & 50 & 200 & 50 & 100 & 50 & 200 & 50 & 200 & $\mathrm{R}$ & $\mathrm{R}$ \\
\hline 5 & G. sepiarium & 50 & 100 & 50 & 200 & 50 & 200 & $\mathrm{R}$ & $\mathrm{R}$ & $\mathrm{R}$ & $\mathrm{R}$ & $\mathrm{R}$ & $\mathrm{R}$ & $\mathrm{R}$ & $\mathrm{R}$ \\
\hline 6 & F. vaillantii & $\mathrm{R}$ & $\mathrm{R}$ & 50 & 100 & $\mathrm{R}$ & $\mathrm{R}$ & $\mathrm{R}$ & $\mathrm{R}$ & 100 & 200 & 50 & 200 & 100 & 100 \\
\hline 7 & F. pinicoca & 50 & 100 & 50 & 200 & 50 & 200 & $\mathrm{R}$ & $\mathrm{R}$ & 100 & 200 & 50 & 100 & 50 & 50 \\
\hline 8 & C. puteana & 50 & 200 & 50 & 100 & 50 & 200 & 50 & 100 & $\mathrm{R}$ & $\mathrm{R}$ & $\mathrm{R}$ & $\mathrm{R}$ & 100 & 100 \\
\hline 9 & A. fumigatus & 50 & 200 & $\mathrm{R}$ & $\mathrm{R}$ & 50 & 200 & $\mathrm{R}$ & $\mathrm{R}$ & 50 & 200 & 50 & 200 & $\mathrm{R}$ & $\mathrm{R}$ \\
\hline
\end{tabular}

Key: VP = Vitellaria paradoxa stem bark, VPH= Vitellaria paradoxa heartwood; $\mathbf{R}=$ Resistance; $\mathbf{M I C}$ $=$ Minimum Inhibitory

Concentration, $\mathbf{M F C}=$ Minimum Fungicidal Concentration

Effect of $V$. Paradoxa fractions and Antibiotics against test bacterial

The antibacterial activities and zones of inhibition (ZOI) of V. paradoxa fractions (VP17, VP28, VP34, VP47, VP23, VP134 and VPH31) indicated that all the test bacteria were sensitive to $V$. paradoxa fractions at ZOI ranging from $20-32$ $\mathrm{mm}$ while the three antibiotics were active at zones of inhibition of $29-39 \mathrm{~mm}$ for all the bacteria except $P$. aeruginosa (Table 3 ). Vitellaria paradoxa stem bark fractions were more active at ZOI of $20-32 \mathrm{~mm}$ compared to the heartwood fraction which was active at ZOI of between 24 $28 \mathrm{~mm}$.

Effect of minimum inhibition concentration and minimum bactericidal concentration (MBC) of $\mathrm{V}$. paradoxa Fractions against Test Bacteria
The minimum inhibition concentration of $V$. paradoxa fractions against the test bacteria showed that stem bark fraction (VP 23) was the most active with MIC of $25 \mu \mathrm{g} / \mathrm{mL}$ while the remaining fractions inhibited the test bacterial growths between MIC of $25-50 \mu \mathrm{g} / \mathrm{mL}$. Similarly, the stem bark fraction (VP 23) of $V$. paradoxa had the least $\mathrm{MBC}$ of $50 \mu \mathrm{g} / \mathrm{mL}$. The remaining fractions obtained from both stem bark and heartwood had MBC of between $100-200$ $\mu \mathrm{g} / \mathrm{mL}$. Pseudomonas aeruginosa was the most resistant bacteria. Although it was resistant to the three antibiotics, its growth was inhibited by only VP134 at MIC $50 \mu \mathrm{g} / \mathrm{mL}$ and killed at MBC of 100 $\mu \mathrm{g} / \mathrm{mL}$.

Table 3: Sensitivity of $V$. paradoxa Fractions and Standard Antibiotics against Test Bacteria

\begin{tabular}{|c|c|c|c|c|c|c|c|c|c|c|c|}
\hline \multirow{2}{*}{\multicolumn{2}{|c|}{ S/No.Test Bacteria }} & \multicolumn{7}{|c|}{$\begin{array}{c}\text { Zone of Inhibition }(\mathrm{mm}) \text { of } V . \\
\text { paradoxa Fractions } \\
(100 \mu \mathrm{g} / \mathrm{mL})\end{array}$} & \multicolumn{3}{|c|}{$\begin{array}{l}\text { Antibiotics } \\
(100 \mu \mathrm{\mu g} / \mathrm{mL})\end{array}$} \\
\hline & & \multicolumn{10}{|c|}{ VP17VP28VP34VP47VP23VP134VPH31Ciprofloxacin Sparfloxacin Cefuroxime } \\
\hline 1 & A. capsulatum & 27 & 0 & 23 & 23 & 28 & 0 & 0 & 0 & 32 & 0 \\
\hline 2 & $\begin{array}{l}\text { Actinobacterium } \\
\text { sp. }\end{array}$ & 0 & 24 & 0 & 0 & 30 & 29 & 0 & 0 & 30 & 0 \\
\hline 3 & $\begin{array}{l}\text { A. } \\
\text { tumefaciens }\end{array}$ & 23 & 23 & 30 & 30 & 0 & 24 & 25 & 32 & 0 & 34 \\
\hline 4 & B. subtilis & 23 & 25 & 25 & 26 & 31 & 0 & 26 & 28 & 35 & 0 \\
\hline 5 & $\begin{array}{l}R . \\
\text { solanacearum }\end{array}$ & 24 & 24 & 26 & 23 & 32 & 0 & 23 & 0 & 30 & 31 \\
\hline $\begin{array}{l}6 \\
7 \\
8\end{array}$ & $\begin{array}{l}\text { E. faecium } \\
\text { E. coli } \\
\text { P. syringae }\end{array}$ & $\begin{array}{c}24 \\
0 \\
20\end{array}$ & $\begin{array}{c}23 \\
0 \\
24\end{array}$ & $\begin{array}{c}25 \\
27 \\
0\end{array}$ & $\begin{array}{l}24 \\
24 \\
26\end{array}$ & $\begin{array}{c}0 \\
28 \\
27\end{array}$ & $\begin{array}{c}0 \\
25 \\
0\end{array}$ & $\begin{array}{c}27 \\
0 \\
28\end{array}$ & $\begin{array}{c}26 \\
34 \\
0\end{array}$ & $\begin{array}{r}0 \\
29 \\
31\end{array}$ & $\begin{array}{c}30 \\
39 \\
0\end{array}$ \\
\hline
\end{tabular}




\begin{tabular}{lllccccccccc}
\hline 9 & $P$. aeruginosa & 0 & 0 & 0 & 0 & 0 & 27 & 0 & 0 & 0 & 0 \\
10 & $P$. mirabilis & 0 & 25 & 23 & 24 & 0 & 24 & 0 & 32 & 33 & 31 \\
\hline
\end{tabular}

Zone of Inhibition < $10 \mathrm{~mm}$ is inactive; $10-13 \mathrm{~mm}$ is partially active; $14-19 \mathrm{~mm}$ is active, and >19 $\mathrm{mm}$ is very active.

\begin{tabular}{|c|c|c|c|c|c|c|c|c|c|c|c|c|c|c|c|}
\hline \multirow{2}{*}{ S/No } & \multirow{2}{*}{ Test Bacteria } & \multicolumn{2}{|c|}{$\begin{array}{c}\text { VP17 } \\
(\mu \mathrm{g} / \mathrm{mL})\end{array}$} & \multicolumn{2}{|c|}{$\begin{array}{c}\text { VP28 } \\
(\mu \mathrm{g} / \mathrm{mL})\end{array}$} & \multicolumn{2}{|c|}{$\begin{array}{c}\text { VP34 } \\
(\mu \mathrm{g} / \mathrm{mL})\end{array}$} & \multicolumn{2}{|c|}{$\begin{array}{c}\text { VP47 } \\
(\mu \mathrm{g} / \mathrm{mL})\end{array}$} & \multicolumn{2}{|c|}{$\begin{array}{c}\text { VP } 23 \\
(\mu \mathrm{g} / \mathrm{mL})\end{array}$} & \multicolumn{2}{|c|}{$\begin{array}{c}\text { VP134 } \\
(\mu g / m L)\end{array}$} & \multicolumn{2}{|c|}{$\begin{array}{c}\text { VPH } 31 \\
(\mu \mathrm{g} / \mathrm{mL})\end{array}$} \\
\hline & & $\begin{array}{c}\text { MI } \\
\text { C }\end{array}$ & $\begin{array}{c}\text { MB } \\
\text { C }\end{array}$ & $\begin{array}{c}\text { MI } \\
\text { C }\end{array}$ & $\begin{array}{c}\text { MB } \\
\text { C }\end{array}$ & $\begin{array}{c}\text { MI } \\
\text { C }\end{array}$ & $\begin{array}{c}\text { MB } \\
\text { C }\end{array}$ & $\begin{array}{c}\text { MI } \\
\text { C }\end{array}$ & $\begin{array}{c}\text { MB } \\
\text { C }\end{array}$ & $\begin{array}{c}\text { MI } \\
\text { C }\end{array}$ & $\begin{array}{c}\text { MB } \\
\text { C }\end{array}$ & $\begin{array}{c}\text { MI } \\
\text { C }\end{array}$ & $\begin{array}{c}\text { MB } \\
\text { C }\end{array}$ & $\begin{array}{c}\text { MI } \\
\text { C }\end{array}$ & \\
\hline 1 & A. $C$ & 25 & 100 & $\mathrm{R}$ & $\mathrm{R}$ & 50 & 100 & 50 & 200 & 25 & 50 & $\mathrm{R}$ & $\mathrm{R}$ & $\mathrm{R}$ & \\
\hline 2 & $\begin{array}{l}\text { Actinobacteria } \\
\text { sp. }\end{array}$ & $\mathrm{R}$ & $\mathrm{R}$ & 50 & 100 & $\mathrm{R}$ & $\mathrm{R}$ & $\mathrm{R}$ & $\mathrm{R}$ & 25 & 50 & 25 & 50 & $\mathrm{R}$ & \\
\hline $\begin{array}{l}3 \\
4\end{array}$ & $\begin{array}{l}\text { A. tumefaciens } \\
\text { B. subtilis }\end{array}$ & $\begin{array}{l}50 \\
50\end{array}$ & $\begin{array}{l}200 \\
200\end{array}$ & $\begin{array}{l}50 \\
50\end{array}$ & $\begin{array}{l}200 \\
100\end{array}$ & $\begin{array}{l}25 \\
50\end{array}$ & $\begin{array}{c}50 \\
100\end{array}$ & $\begin{array}{l}25 \\
50\end{array}$ & $\begin{array}{c}50 \\
100\end{array}$ & $\begin{array}{c}\mathrm{R} \\
25\end{array}$ & $\begin{array}{c}R \\
50\end{array}$ & $\begin{array}{c}50 \\
\mathrm{R}\end{array}$ & $\begin{array}{c}100 \\
\mathrm{R}\end{array}$ & $\begin{array}{l}50 \\
50\end{array}$ & \\
\hline 5 & $\begin{array}{l}R . \\
\text { solanacearum }\end{array}$ & 50 & 200 & 50 & 100 & 50 & 100 & 50 & 200 & 25 & 50 & $\mathrm{R}$ & $\mathrm{R}$ & 50 & \\
\hline 6 & E. faecium & 50 & 200 & 50 & 100 & 50 & 100 & 50 & 100 & $\mathrm{R}$ & $\mathrm{R}$ & $\mathrm{R}$ & $\mathrm{R}$ & 25 & \\
\hline 7 & E. coli & $\mathrm{R}$ & $\mathrm{R}$ & $\mathrm{R}$ & $\mathrm{R}$ & 25 & 50 & 50 & 100 & 25 & 50 & 50 & 100 & $\mathrm{R}$ & \\
\hline 8 & P. syringae & 50 & 200 & 50 & 100 & $\mathrm{R}$ & $\mathrm{R}$ & 50 & 100 & 25 & 50 & $\mathrm{R}$ & $\mathrm{R}$ & 25 & \\
\hline 9 & P. aeruginosa & $\mathrm{R}$ & $\mathrm{R}$ & $\mathrm{R}$ & $\mathrm{R}$ & $\mathrm{R}$ & $\mathrm{R}$ & $\mathrm{R}$ & $\mathrm{R}$ & $\mathrm{R}$ & $\mathrm{R}$ & 25 & 50 & $\mathrm{R}$ & \\
\hline 10 & P. mirabilis & $\mathrm{R}$ & $\mathrm{R}$ & 50 & 100 & 50 & 100 & 50 & 50 & $\mathrm{R}$ & $\mathrm{R}$ & 50 & 100 & $\mathrm{R}$ & \\
\hline
\end{tabular}

Table 4: Minimum Inhibition Concentration and minimum Bactericidal concentration (MBC) of $V$. paradoxa Fractions against Test Bacteria

Key: VP = Vitellaria paradoxa tem bark; VPH = Vitellaria paradoxa heartwood; $\mathrm{R}=$ Resistance; MIC

$=$ Minimum Inhibitory Concentration, $\mathrm{MBC}=$ minimum bactericidal concentration

\section{Discussion}

Vitellaria paradoxa heartwood fraction (VPH22) was characterised as spinasterol while the other fractions were fatty. Pohl et al. (2011) noted that fatty acids contain antibacterial, antimalarial and antifungal activity. It was observed that though they may not be as efficient as chemical fungicides, the environmental risks are less. Meneses-Sagrero (2017) reported spinasterol in the methanol extract of Stegnosperma halimifolium to have anti-proliferative (a substance used to prevent or retard the spread of cells) properties. El Kharrasi et al. (2014) in their studies observed that spinasterol obtained from argan oil and cactus pear seed oil had inhibitory activity on the cellular growth of microglial murine cells. Meneses-Sagrero et al. (2017) reported spinasterol compounds isolated from methanol extract of Pueraria mirifica roots to exhibit strong anti-proliferative effects against breast cancer and cervical cells. Meneses-Sagrero et al. (2017) also reported that spinasterol isolated from the n-hexane fraction and methanol extracts of $S$. halimifolium stem had antiproliferative effects on cervical cancer and murine macrophage cancer cells. Csupor-Loaffer et al. (2011) observed that spinasterol isolated from Conyza canadensis plant species had anti- proliferative activity against breast cancer cells (MCF-7), cervical cancer (HeLa) cell line, noncancerous human fetal fibroblast (MRC-5) cell line and epidermoid carcinoma (A431) cell lines. Kuiate et al. (2009) reported spinasterol as one the most active compounds of Microglossa angolensis with active antibacterial and antifungal principles. The study of antifungal activity by Johann et al. (2011) on five species of polygala ( $P$. campestris, $P$. cyparissias, $P$. paniculata, $P$. pulchella and $P$. sabulosa) revealed that spinasterol compound showed a wide activity against the test microbes. Garba and Salihu, (2011) had isolated ketone (2), 1-phenyl-1, 4pentanedione and ester (1), 2-0-butyl-1-0-(2'ethylhexyl) benzene-1, 8-dicarboxylate from Vitellaria paradoxa. Fatty acids with their derivatives are promising great potential as environmentally friendly antifungal agents that can lead to novel antifungal drugs (Pohl et al., 2011).

The zones of inhibition of $V$. paradoxa fractions $(18-24 \mathrm{~mm})$ were at the same range of $25 \mathrm{~mm}$ - $31 \mathrm{~mm}$ recorded for the three antibiotics. Fomitopsis pinicoca fungus was resistant to all antibiotics but was sensitive to all fractions of $V$. paradoxa at zones of inhibition of $18-24 \mathrm{~mm}$. 
These values are within the very active ( $>19 \mathrm{~mm}$ ) range described by Guevara, (2005), as a standard zone of inhibition of antibiotics. Boyejo et al. (2019) reported zones of inhibition of $V$. paradoxa ethanol crude bark extract on dermatophytes as $20.5 \mathrm{~mm}$ (Microsporum audouinii), $19.5 \mathrm{~mm}$ (Microsporum ferrugenum) and $17.5 \mathrm{~mm}$ (Trichophyton rubrum) while the acetone bark extract were $19 \mathrm{~mm}$ (Microsporum audouinii), $17.5 \mathrm{~mm}$ (Microsporum ferrugenum) and $16.5 \mathrm{~mm}$ (Trichophyton rubrum) at concentration of $250 \mathrm{mg} / \mathrm{mL}$.

The zone of inhibition of $V$. paradoxa fractions on all test bacteria ranged from $20-32 \mathrm{~mm}$ while the antibiotics were between 29 - $39 \mathrm{~mm}$. Although ZOI recorded for $V$. paradoxa fractions were slightly lower than the ones for the three antibiotics, they both were very active according to Guevara, (2005) who reported ZOI greater than $19 \mathrm{~mm}$ to be very active. Garba and Salihu, (2011) observed that ketone (2), 1-phenyl-1,4pentanedione and ester (1), 2-O-butyl-1-O-(2'ethylhexyl) benzene-1,8-dicarboxylate compounds isolated from $V$. paradoxa recorded zones of inhibition of $25-28 \mathrm{~mm}$ against $S$. aureus and $B$. subtilis (gram positive bacteria) and $E$. coli, $S$. typhi and $P$. aeruginosa (gram negative) at the concentration of $7 \times 102 \mu \mathrm{g} \mathrm{cm}-$ 3.

Minimum inhibitory concentrations (MIC) of $V$. paradoxa fractions were active at $50 \mu \mathrm{g} / \mathrm{mL}$ against all test fungi. At minimum fungicidal concentration (MFC) of between $50-200 \mu \mathrm{g} / \mathrm{mL}$, all test fungi were killed. This performance of $V$. paradoxa may be due to the presence of spinasterol compounds. Freire et al. (2005) reported the presence of spinasterol as natural sources of bioactive sterols from the wood and bark of the Acacia species ( $A$. longifolia. $A$. dealbata, $A$. melanoxylon and $A$. retinodes). Spinasterol and a-Spinasterol have been reported by Ravikumar et al. (2010) to show antiproliferative effects that inhibit cell growth. Spinasterol has also been demonstrated to be a powerful inhibitor of glomerular mesangial cell multiplication (Ravikumar et al., 2010). Villasenor and Domingo (2000) reported result of in vivo studies that proved the efficacy of antitumorigenic activity of spinasterol to skin tumours without co-tumour or co-carcinogen promoter activities as well as possessing active antiproliferative effect on gynaecological cancer cells.

The MIC of $V$. paradoxa on all the test bacteria was between $25-50 \mu \mathrm{g} / \mathrm{mL}$ while the $\mathrm{MBC}$ was between $50-200 \mu \mathrm{g} / \mathrm{mL}$. Least MIC $(25 \mu \mathrm{g} / \mathrm{mL})$ and $\mathrm{MBC}(50 \mu \mathrm{g} / \mathrm{mL})$ were recorded for the stem bark. This implies that fractions from the stem bark were more potent on the test bacteria than on the fractions from the heartwood. Kuete et al. (2009) reported MIC of $625 \mu \mathrm{g} / \mathrm{mL}$ for Citrobacter freundii, 156 - $625 \mu \mathrm{g} / \mathrm{mL}$ for Escherichia coli, Bacillus cereus and Pseudomonas aeruginosa; 312 - 625 for $\mu \mathrm{g} / \mathrm{mL}$ Klebsiella pneumoniae 312 $\mu \mathrm{g} / \mathrm{mL}$ for Salmonella typhi; $39-312 \mu \mathrm{g} / \mathrm{mL}$ for Staphylococcus aureus and $156-312 \mu \mathrm{g} / \mathrm{mL}$ for Streptococcus faecalis from Ficus ovate fractions. Kuete et al. (2009) also recorded MBC of $>625$ $\mu \mathrm{g} / \mathrm{mL}$ for Citrobacter freundii; $156-625 \mu \mathrm{g} / \mathrm{mL}$ Escherichia coli; 625 - > $625 \mu \mathrm{g} / \mathrm{mL}$ for Pseudomonas aeruginosa and Klebsiella pneumonia; $625 \mu \mathrm{g} / \mathrm{mL}$ Salmonella typhi and Streptococcus faecalis, 312 - > $625 \mu \mathrm{g} / \mathrm{mL}$ Bacillus cereus and 78 - $625 \mu \mathrm{g} / \mathrm{mL}$ Staphylococcus aureus, respectively from Ficus ovate fractions.

This study revealed that $V$. paradoxa heartwood fractions possess spinasterol. The stem bark was more active on wood fungi compared to the heartwood fraction. This agrees with Boyejo et al. (2019) who reported that stem bark extract of $V$. paradoxa was most active compared to the leaves and roots extracts. The presence of spinasterol in the heartwood could be due to the deposition and accumulation of extractives in the heartwood of the tree over a period of time.

\section{Conclusion}

Spinasterol compound was isolated from the heartwood of Vitellaria paradoxa. All fractions exhibited high antifungal and antibacterial activity as it controlled all test wood fungi and bacteria. Although Fomitopsis pinicoca fungus and Pseudomonas aeruginosa bacteria were resistant to all antibiotics, they were sensitive to fractions of $V$. paradoxa probably because of its spinasterol compound which is a natural source of bioactive sterols. The stem bark was more active on wood fungi compared to the heartwood fraction. The results of ZOI, MIC and MFC showed that $V$. paradoxa stem bark heartwood fractions were 
very efficient in inhibiting the growth of test wood rot fungi and wood colonising bacteria; hence the species should be explored as a potential source of bioactive fungicides.

\section{Reference}

Ahmed, R.N., Abdulrahaman, A. A. and Sani, A. (2012). In vitro evaluation of antifungal potentials of methanolic extracts of three organs of Vitellaria paradoxa (Shea plant). J. Sci. Tech. Math. \& Edu. 8(2): $8-15$.

Ahmed R. N., and Sani A. (2013). Antimycotic activity and toxicological effects of stem bark extract of Vitellaria paradoxa in wistar rats. Sci. Inter. (Lahore), 25(1):91-102.

Ahmed R.N., Sani A., and Igunnugbemi O. O. (2009). Antifungal profiles of extracts of Vitellaria paradoxa (Shea-butter) Bark. Ethnobot Leaflets, 13: 679-688.

Ajijolakewu, K. A. and Awarun F. J. (2015). Comparative Antibacterial Efficacy of Vitellaria paradoxa (Shea Butter Tree) Extracts Against Some Clinical Bacterial Isolates. Not. Sci. Biolo. $7(3): 264-268$.

Alexandri, E., Ahmed, R., Siddiqui, H., Choudhary, M. I., Tsiafoulis, C. G., and Gerothanassis, I. P. (2017). High resolution NMR spectroscopy as a structural and analytical tool for unsaturated lipids in solution. Molecules, 22(10), 1663.

Animasaun, D. A. Oyedeji, S., Olorunmaiye, K. S., Azeez, M. A., Tijani, I. A. and Morakinyo, J. A. (2019). Morpho-chemical divergence and fatty acid profile of shea tree seeds (Vitellaria paradoxa) collected from different locations in Kwara State, Nigeria. Act. Bot. Croa. 78 (1), 1724

Audu, J. and Awulu, J.O. (2017). Effect of extraction methods on some food and biodiesel properties of shea-nut oil ( Vitellaria paradoxa). J. Posthar. Tech. 5(1): 17-26.

Blanchette, R. A. (2000). A review of microbial deterioration found in archaeological wood from different environments. Inter. Biodeter. \& Biodegra. 46: 189-204.

Boyejo A.O., Azeez I.A., Owolabi S.L., and Issah A.O. (2019). Antifungal and Phytochemical Screening of Extract from Vitellaria Paradoxa (Shea Butter Tree) Leaves, Barks and Roots on Dermatophytes. Inter. J. Scient. \& Res. Publi. 9(6): $884-891$.

Cheung, H. T., and Williamson, D. G. (1969). NMR signals of methyl groups of triterpenes with oxygen functions at positions 2, 3 and 23 . Tetrahedron, 25(1), 119-128.

Csupor-Loaffer, B., Hajdu, Z., Zupko, I., Molnar, J., Forgo, P., Vasas, A., Kele, Z., Hohmann, J., 2011. Antiproliferative constituents of the roots of Conyza canadensis. Plan. Medi. 77, 1183-1188.

Ekhuemelo, D. O., Agbidye, F. S., Anyam, J. V. and Ugba, R. B. (2018). Antimicrobial effect of isolated compound of Anadelphia afzeliana (Rendle) Stapf on selected wood fungi and bacteria in Makurdi, Nigeria. Nig. J. Biotech. 35(2): 108-120.

El Kharrasi, Y., Samadi, M., Lopez, T., Nury, T., el Kebbaj, R., Andreoletti, P., El Hajj, H., Vamecq, J., Moustaid, K., Latruffe, N., El Kebbaj, L., Masson, D., Lizard, G., Nasser, B., and CherkaouiMalki, M., (2014). Biological activities of schottenol and spinasterol, two natural phytosterols present in argan oil and in cactus pear seed oil, on murine miroglial BV2 cells. Bioch. \& Biophy. Res. Comm. 446, 798-804.

El-Mahmood A. M., Doughari J. H., Ladan N. (2008). Antimicrobial screening of stem bark extract of Vitelleria paradoxa against some enteric pathogenic microorganisms. Afri. J. Pharm. \& Pharmaco. 2(5):089-094.

Freire, C. S. R., Coelho, D. S. C., Santos, N. M., Silvestre, A. J. D., and Pascoal Neto, C. (2005). Identification of $\Delta 7$ phytosterols and phytosteryl glucosides in the wood and bark of several Acacia species phytosterols and 
phytosteryl glucosides in the wood and bark of several Acacia species. Lipi. 40(3): 317-322.

Fodouop, S. P. C., Gatsing, D., Tangue, B. T., Tagne, R. S., Tala, S. D., Tchoumboué, J., and Kuiate, J. R. (2015). Effect of Salmonella typhimurium infection on rat's cell oxidation and in vivo antioxidant activity of Vitellaria paradoxa and Ludwigia abyssinica aqueous extract. Asian Pacif. J. Trop. Dis. 5(1), 38-46.

Garba S. and Salihu L. (2011). Antibacterial Activities of 2-0-butyl-1-0-(2'-ethylhexyl) benzene-1,8-dicarboxylate and 1-phenyl-1,4pentanedione Isolated from Vitellaria paradoxa Root Bark. Asian J. of Scient. Res. 4 (2): 149-157.

Guevara, B. Q. (2005). A Guidebook to Plant Screening: Phytochemical and Biological, Revised Edition, UST Publishing House, Manila. Pp 156.

ICRAF (2000). International Centre for Research in Agroforestry. Agroforestree Database 2000 IPGRI, INIA (2006). Descriptors for Shea tree (Vitellaria paradoxa). International Plant Genetic Resources Institute, Rome, Italy; Instituto Nacional de Investigación y Tecnología Agraria y Alimentaria, Madrid, Spain. P 63.

Johann, S. Mendes, B.G., Missau, F.C., deResende, M.A., and Pizzolatti, M.G. (2011). Antifungal activity of five species of Polygala. Braz. J. Microb. 42: 1065-1075.

Kalgo, M.U., Hamid, K.M., Muhammad, U. A., Balarabe, A., Yeldu, M. H., Yahaya, I.S., Kalgo, Z.M. Aliyu, B. and Y. G. (2019). Bala Effects of aqueous stem bark extract of Vitellaria paradoxa on human neutrophil function and viability. Intern. J. Biolog. \& Med. Res., 10(3):6782-6787.

Kuete V, Nana F, Ngameni B, Mbaveng AT, Keumedjio F, Ngadjui BT. (2009). Antimicrobial activity of the crude extract, fractions and compounds from stem bark of Ficus ovata (Moraceae). J. Ethnopharm., 124,556 - 561.

Kuiate, J., Tene, M., Tane, P., and Tamokou, J. (2009). Antimicrobial clerodane diterpenoids from Microglossa angolensis Oliv. et Hiern. Ind. J. Pharmaco. 41(2), 60.
Kuta, F. A., Oyedum U., Garba S. A., Bala, J. D. and Adedeji, S. A. (2017). Antibacterial Activity of Vitellaria paradoxa on some Enteric Bacteria. Nig. J. Microb. 31(1): 3882-3892.

Lladó, S., Žifčáková, L., Větrovský, T., Eichlerová, I., and Baldrian, P. (2015). Functional screening of abundant bacteria from acidic forest soil indicates the metabolic potential of Acidobacteria subdivision 1 for polysaccharide decomposition. Bio. \& Fert. Soi. 52(2), 251-260.

Marcot B. G. (2007). A Review of the Role of Fungi in Wood Decay of Forest Ecosystems. U.S. Department of Agriculture. Research note PNWRN-575. Pp 1- 31.

Meneses-Sagrero, S. E., Navarro-Navarro, M., Ruiz-Bustos, E., Del-Toro-Sánchez, C. L., Jiménez-Estrada, M., and Robles-Zepeda, R. E. (2017). Antiproliferative activity of spinasterol isolated of Stegnosperma halimifolium (Benth, 1844). Sau. Pharm. J., 25(8), 1137-1143.

Moore, S., (2008). The role of Vitellaria paradoxa in poverty reduction and food security in the Upper East region of Ghana. Ear. \& Environ. 3, 209-245.

Olasunkanmi, O.O., Akinpelu, D. A., Adeniyi, P. O., Ajayi, O. F., Omololu-Aso J. and Olorunmola F. O. (2017).Investigations into Antibacterial, Phytochemical and Antioxidant Properties of Vitellaria paradoxa (Gaertn.) Stem Bark Extracts. J. Pharma. Res. Intern. 20(5): 1-17, 2017.

Pohl C. H., Kock J. L. F. and Thibane V. S. (2011). Antifungal free fatty acids: A Review. Science against microbial pathogens: communicating current research and technological advances $A$. Méndez-Vilas (Ed.). Pp61 - 71.

Prescott M. L, Harley P. J. and Klein A. D. (2002). Microbiology. 7th edition. McGraw Hill Inc.

Ravikumar, Y. S., Mahadevan, K. M., Manjunatha, $\mathrm{H}$. and Satyanarayana, N. D. (2010). Antiproliferative, apoptotic and antimutagenic activity of isolates from Polyalthiacerasoides seeds. Phytomed. 17(7), 513-518. 
Seibert, U. (2007). Languages of Benue state, Nigeria, B. Ed project Report, Department of Languages department of languages and linguistics, University of Jos; 86p.

Shomkegh, S. A., Mbakwe, R. and Sale F. A. (2016). Ethnobotanical Survey of Wild Plants Utilized for Craft Making and Local Construction among the Tiv People of Benue State, Nigeria. J. Agric. \& Ecol. Res. Intern. 9(3): 1-11.

Sun, Y., and Yasukawa, K. (2008). New antiinflammatory ergostane-type ecdysteroids from the sclerotium of Polyporus umbellatus.

Bioorganic \& medicinal chemistry letters, 18(11), 3417-3420.

Teketay, D. Gurmu, D. and Bekele, T. (2003). Vitellaria paradoxa: a multipurpose industrial oilseed tree. Wal. 23: 3-23.
Ugese, F. D., Baiyeri, P. K. and Mbah, B. N. (2008). Nutritional composition of shea (Vitellaria paradoxa) fruit pulp across its major distribution zones in Nigeria. Fruits: Th. Intern. J.of Trop. \& Subtrop. Horticu. 63 (3) $163-170$.

Villaseñor, I. M., and Domingo, A. P. (2000). Anticarcinogenicity potential of spinasterol isolated from squash flowers. Teratogenesis, carcinogenesis, and mutagenesis, 20(3), 99-105.

Warra, A.A. (2011). Cosmetic Potentials of African Shea Nut (Vitellaria paradoxa) Butter. Cur. Res. Chem. 3: 80-86.

Ziblim, A. I., Abdul-Rasheed, S. and Aikins, T. K. (2015). Forage species used by livestock in the Kumbungu District of the Northern Region, Ghana. UDS Intern. J. Devel. [UDSIJD], 1(1): 18 $-29$. 